\title{
CORRECTION
}

Wolfgang Ehlers

\section{Correction to: Darcy, Forchheimer, Brinkman and Richards: classical hydromechanical equations and their significance in the light of the TPM}

Published online: 21 June 2021

(C) The Author(s) 2021

\section{Correction to: Arch Appl Mech \\ https://doi.org/10.1007/s00419-020-01802-3}

The article "Darcy, Forchheimer, Brinkman and Richards: classical hydromechanical equations and their significance in the light of the TPM", written by "Wolfgang Ehlers", was originally published Online First without Open Access. As Open Access funding enabled and organized by Projekt DEAL, the copyright of the article has been changed to (C) The Author(s) and the article is forthwith distributed under the terms of the Creative Commons Attribution.

Funding note has also been updated in the original article.

Open Access This article is licensed under a Creative Commons Attribution 4.0 International License, which permits use, sharing, adaptation, distribution and reproduction in any medium or format, as long as you give appropriate credit to the original author(s) and the source, provide a link to the Creative Commons licence, and indicate if changes were made. The images or other third party material in this article are included in the article's Creative Commons licence, unless indicated otherwise in a credit line to the material. If material is not included in the article's Creative Commons licence and your intended use is not permitted by statutory regulation or exceeds the permitted use, you will need to obtain permission directly from the copyright holder. To view a copy of this licence, visit http://creativecommons.org/licenses/by/4.0/.

Publisher's Note Springer Nature remains neutral with regard to jurisdictional claims in published maps and institutional affiliations.

The original article can be found online at https://doi.org/10.1007/s00419-020-01802-3.

W. Ehlers (凶)

Institute of Applied Mechanics, University of Stuttgart, Pfaffenwaldring 7, 70569 Stuttgart, Germany

e-mail: Wolfgang.Ehlers@mechbau.uni-stuttgart.de 